\title{
Relationship between the inflammatory tumor microenvironment and different histologic types of canine mammary tumors
}

\author{
Thiago Alves de Souza ${ }^{\mathrm{a}, \mathrm{b}}$, Cecília Bonolo de Campos $^{\mathrm{b}}$, Aline De Biasi Bassani Gonçalves ${ }^{\mathrm{b}}$, \\ Fernanda Camargo Nunes ${ }^{\mathrm{b}}$, Lidianne Narducci Monteiro ${ }^{\mathrm{b}}$, Rosemeri de Oliveira Vasconcelos ${ }^{\mathrm{c}}$, \\ Geovanni Dantas Cassali ${ }^{\mathrm{b}, *}$
}

a Programa de Pós-Graduação em Medicina Veterinária, FCAV/UNESP, Jaboticabal, SP, Brazil

b Laboratório de Patologia Comparada, Departamento de Patologia Geral, ICB/UFMG, Belo Horizonte, MG, Brazil

${ }^{\mathrm{c}}$ Departamento de Patologia Veterinária, FCAV/UNESP, Jaboticabal, SP, Brazil

\section{A R T I C L E I N F O}

\section{Keywords:}

Cancer

Dogs

Histochemistry

Immunohistochemistry

Inflammation

\begin{abstract}
A B S T R A C T
Mammary neoplasms are the tumors with higher incidence in female dogs. Among the factors that contribute for the development of this and other neoplasms, the inflammatory tumor microenvironment plays a crucial role. Several studies reported important roles for lymphocytes, macrophages, plasma cells, neutrophils, eosinophils and mast cells in this context. In the present study, our aim was to evaluate the number of profile cells of inflammatory cells and area of tumor fibrosis and the relation of these features with canine mammary tumors of different histologic and clinical presentation (benign mixed tumor, carcinoma in mixed tumor, solid carcinoma and tubular carcinoma) Counting and staining of inflammatory cells and tumor fibrosis were performed through histochemistry, while counting and staining of $\mathrm{CD}^{+}, \mathrm{TCD}^{+}$and $\mathrm{FOXP} 3^{+}$lymphocytes were performed through immunohistochemistry. Statistical analysis of the association between densities of inflammatory cells, tumor fibrosis and histologic types revealed significant difference for plasma cells $(p=.035)$, neutrophils $(p=.0113)$, macrophages $(p=.0047)$, and tumor fibrosis $(p=.05)$. The found data suggest associations between high number of neutrophils and aggressive mammary tumors, between high densities of plasma cells, macrophages and CD8 ${ }^{+}$cells and between low number of profile cells of CD4 ${ }^{+}$cells and less aggressive tumors. Larger areas of tumor fibrosis showed relation to more aggressive canine mammary tumors.
\end{abstract}

\section{Introduction}

Mammary neoplasms represent approximately $50 \%$ of the tumor occurrence in female dogs. These tumors are more frequent in middleaged and elderly animals, with no breed predisposition, and may show correlation with reproductive status, use of progestogen and episodes of pseudocyesis (De Oliveira et al., 2003).

In addition to the characteristics aforementioned, the inflammatory microenvironment also plays an important role in tumor development (Mantovani et al., 2008). It is known that several types of inflammatory processes, different as to cause, mechanism, consequence and intensity, may promote neoplastic development and progression (Grivennikov et al., 2010). Within the tumor microenvironment, angiogenesis is a fundamental feature, once it is responsible for the formation of a vascular network that facilitates the tumor nutrition and growth, besides allowing the recruitment of inflammatory cells and spreading of neoplastic cells (Hasan et al., 2002; Sharma et al., 2005; Luong et al.,
2006). Based on recent studies, the inflammatory cell types that have most been addressed in this microenvironment are T and B lymphocytes, macrophages and neutrophils (Balkwill et al., 2012).

Among the different populations of $\mathrm{T}$ lymphocytes, the cytotoxic $\mathrm{T}$ lymphocytes are characterized mainly by the presence of CD8 marker and are generally associated with better prognosis (Mahmoud et al., 2011; Miyashita et al., 2015; Preston et al., 2013). However, Th2 lymphocytes, characterized by the presence of CD4 marker (Fridman et al., 2012) are related to worse prognostics (Macchetti et al., 2006). Regulatory $\mathrm{T}$ lymphocytes (Treg) are characterized by the immunophenotype $\mathrm{CD}^{+} \mathrm{CD}^{+} 5^{+} \mathrm{FOXP}^{+}$and are associated with worse prognosis and lower survival (Hsieh et al., 2012).

B lymphocytes and plasma cells are associated with tumor growth promotion (Fridman et al., 2012) and lower survival rates in human patients with breast and ovarian cancer (Mohammed et al., 2013; Lundgren et al., 2016). However, Knief et al. (2016); Yoon et al. (2011) reported a relationship between the increase in plasma cells and B

\footnotetext{
* Corresponding author at: Laboratório de Patologia Comparada, Departamento de Patologia Geral, ICB/UFMG, Av. Antonio Carlos, 6627, 31270-901 Belo Horizonte, MG, Brazil.

E-mail address: cassalig@icb.ufmg.br (G.D. Cassali).
} 
lymphocytes numbers, breast cancers with better prognosis and prolonged survival in human patients with esophagogastric transition adenocarcinoma.

Tumor-associated neutrophils show pro-tumorigenic roles through angiogenesis stimulation (Nozawa et al., 2006), increased degradation of extracellular matrix (De Larco et al., 2004) and immunosuppression (Youn and Gabrilovich, 2010). These cells also exert antitumor activity through direct cytotoxicity (Dissemond et al., 2003), cell-mediated cytotoxicity (Guettinger et al., 2010; Hubert et al., 2011) and stimulation of effector T cells (Fridlender et al., 2010).

Regarding the macrophages, Qian and Pollard (2010) reported protumorigenic effect of these cells in experimental models of cancer, similar to Bingle et al. (2002), who observed worse prognosis in tumors that showed abundance of this cell type. However, the increase of macrophages in the tumor microenvironment may also be associated with better prognosis and prolonged survival in large cell lung carcinomas (Almatroodi et al., 2016).

The role of eosinophils in the tumor microenvironment is determined by the release of mediators that recruit $\mathrm{CD}^{+} \mathrm{T}$ cells and natural killers cells (NK) (Carretero et al., 2015; Furbert-Harris et al., 2003), guaranteeing antitumor and protective activities. On the other hand, Amini et al. (2007) showed that eosinophils are not present in significant number in invasive mammary carcinomas, making it impossible to elucidate the role of these cells in these types of neoplasms.

The presence and activity of mast cells in the tumor microenvironment remain controversial. Some studies reported an association between high number of profile cells of mast cells in the tumor microenvironment, greater release of angiogenic factors and high number of profile cells of microvasculature in human and canine mammary carcinomas (Cimpean et al., 2017; Lavalle et al., 2010). On the other hand, Amini et al. (2007), Dabiri et al. (2004) and Rajput et al. (2008) observed, in human mammary carcinomas, that a high number of profile cells of mast cells was related to low grade tumors and estrogen receptor positivity, to patients without lymph node involvement and to patients with better prognosis, respectively.

In addition to the roles of inflammatory cells, De Kruijf et al. (2011) and Gujam et al. (2014) demonstrated a prognostic importance of tumor fibrosis in human mammary neoplasms by verifying a relationship between larger areas of tumor fibrosis, survival time and relapsefree time. Furthermore, Liu et al. (2014) and Zhang et al. (2015) found a similar relationship in cervical carcinoma and large cell lung carcinoma in humans, respectively.

Although the current literature shows several studies that reports the participation of inflammatory cells and tumor fibrosis in tumor development and progression in human species, the canine species lacks data regarding the role of inflammatory tumor microenvironment in the same context.

The present study aims to evaluate the densities of inflammatory cells and tumor fibrosis percentage in mammary neoplasms and relate these parameters to four different histologic types of this neoplasia in canine species.

\section{Material and methods}

Samples of mammary neoplasms from 38 bitches were selected from paraffin blocks of the Comparative Pathology Laboratory - Biological Sciences Institute of the Federal University of Minas Gerais (UFMG, Belo Horizonte, MG). Mammary neoplasms were classified according to the World Health Organization (Misdorp et al., 1999) and the guidelines of the second consensus for diagnosis, prognosis and treatment of canine mammary tumors (Cassali et al., 2014).

Samples were divided in benign mixed tumor (BMT, $n=7$ ), carcinoma in mixed tumor (CMT, $n=16$ ), solid carcinoma (SC, $n=8$ ) and tubular carcinoma (TC). Paraffin blocks were cut to a thickness of $3 \mu \mathrm{m}$ and, subsequently, either stained with hematoxylin and eosin for tumor classification, identification of micro invasion or invasion areas and counting of lymphocyte, plasma cells and macrophages under light microscopy, or submitted to histochemistry and immunohistochemistry techniques for counting of mast cells, eosinophils and tumor fibrosis percentage.

For immunohistochemistry and histochemistry techniques, six cuts of each histologic type were mounted on gelatinized slides, and then dewaxed and rehydrated. Antigen retrieval for anti-CD4 antibodies (VMRD, monoclonal, clone DH29A, 1: 100), anti-CD8 (ABD Serotec, monoclonal, clone YTS169.4, 1:40), FOXP3 (Spring, polyclonal, clone SP97, 1: 500) was made with sodium citrate solution $(\mathrm{pH}=6.0)$ in water bath $\left(90^{\circ} \mathrm{C} / 20 \mathrm{~min}\right)$. Blockages of endogenous peroxidase and nonspecific proteins were performed with commercial solutions from Novolink system (Leica Biosystems Newcastle Ltd., UK) according to the manufacturer's recommendations. Primary antibodies were incubated for $16 \mathrm{~h}$ at $4{ }^{\circ} \mathrm{C}$ and, thereafter, the secondary antibody and polymer (Novolink) were applied according to the manufacturer's recommendations. Counterstaining was done with Harris Hematoxylin and immunoreactivity was revealed with chromogenic solution of $3,3^{\prime}$ diaminobenzidine (DAB) from Novolink system for $3 \mathrm{~min}$.

Histochemical staining of toluidine blue $(1 \%)$ for identifying mast cells, congo red $(0.5 \%)$ for identifying eosinophils and Sirius red to evidence areas of tumor fibrosis were performed according to the methods already recommended by Prophet et al. (1992) and Meyerholz et al. (2010).

Images from the four histologic types of tumors were captured on a Spot Insight Color digital camera adapted to an Olympus BX-40, through the capture software SPOT $^{\circledast}$ version 3.4.5, to count the inflammatory cells and determine tumor fibrosis percentage. To evaluate the inflammatory infiltrate by H\&E staining, images of eight hotspots (i.e. areas that showed intense concentration of inflammatory cells) from each slide were captured in $100 \times$ objective, followed by differential counting of lymphocytes, plasma cells, neutrophils and macrophages through ImageJ software version 1.41. The values obtained in the eight hotspots were summed to provide total value of each cell type and the medians of these values were used to classify the infiltrates as to their number of profile cells (low, moderate and high) according to what was proposed by Estrela-Lima et al. (2010).

For counting of eosinophils, mast cells, $\mathrm{TCD}^{+}, \mathrm{TCD}^{+}$and FOXP $3^{+}$lymphocytes, images of five hotspots (i.e. areas that showed intense concentration of inflammatory cells) from each sample were captured in $40 \times$ objective, followed by counting of labeled cells through ImageJ software (version 1.41). The values obtained in the five hotspots were summed to obtain the total value of each cell type.

Regarding tumor fibrosis percentage, three images of each histologic type were captured in $10 \times$ objective and analyzed with ImageJ software (version 1.41). For the analysis, each image was decompound into three other images through the plug-in "color deconvolution". Each new image highlighted one single color (cyan, white, magenta), being that the red color evidenced the areas with and without connective tissue within the tumor. Tumor fibrosis percentage of each image was obtained through automatic counting of the pixels of red colored images, as it is seen in Fig. 2i. From the three found values, a mean was calculated for each sample.

Kruskal-Wallis and Mann-Whitney and Kaplan-Meyer statistical tests were performed with GraphPad Prism software (version 6) to evaluate the relationship between cell types and different histologic types of mammary tumors. Evaluation of the relationship between tumor fibrosis and histologic types of mammary tumors was performed through parametric analysis of variance (ANOVA) and $t$-test. Multivariate evaluation encompassing all observed parameters was done through software $\mathrm{R}$ (version 3.2.4).

\section{Results}

Lymphocytes were the predominant cell type in the inflammatory infiltrate of all histologic types of mammary neoplasms, while the 

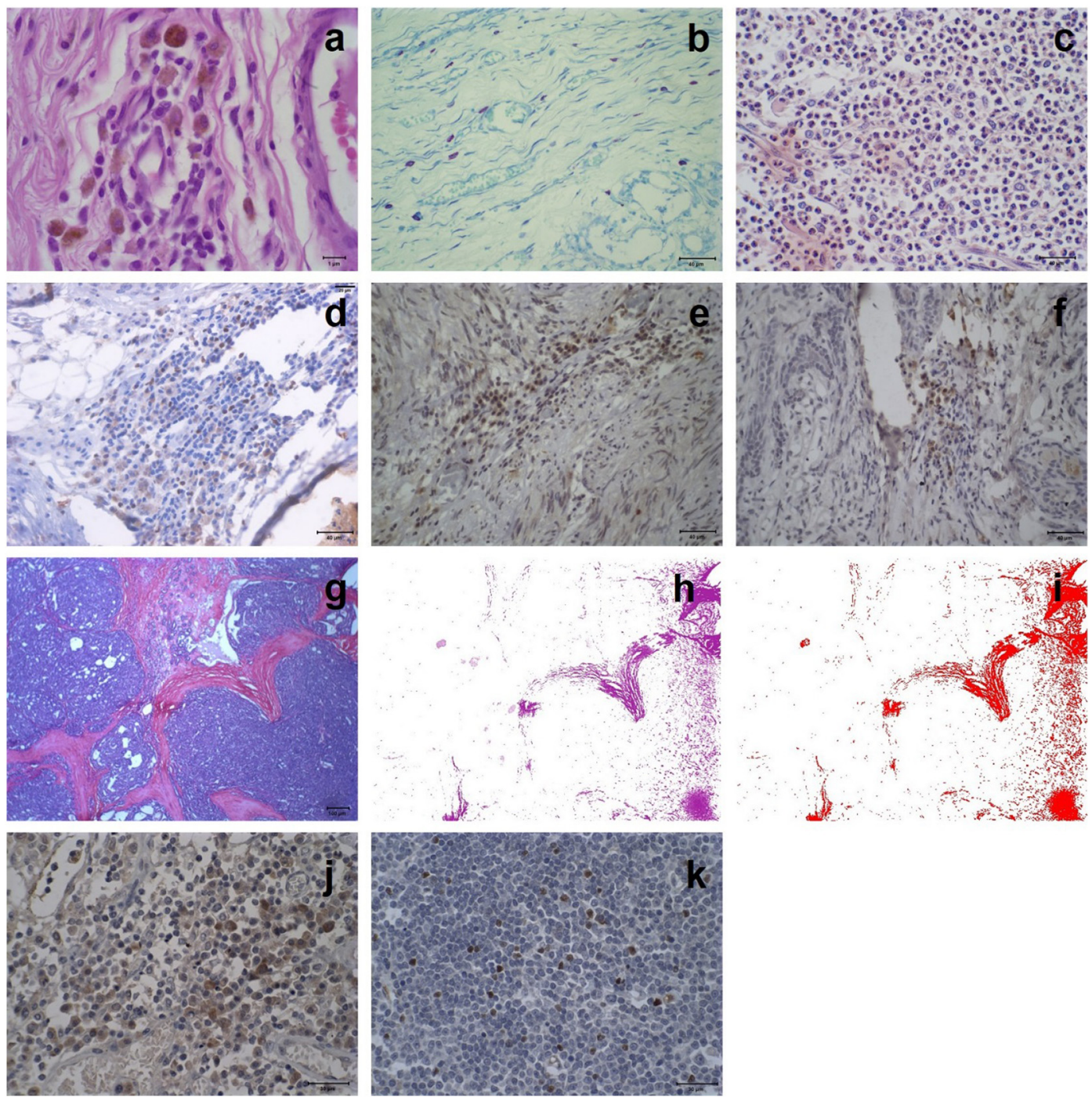

Fig. 1. Photomicrographs showing inflammatory cells and tumor fibrosis through histochemistry and immunohistochemistry techniques. 1a: Mononuclear inflammatory infiltrate in peritumoral region. Fine arrow: Plasma cells. Broad arrow: Macrophages with hemosiderin. Arrowhead: lymphocytes (H\&E; 100 $\times$ ). 1b: Presence of mast cells in peritumoral region (arrow) (toluidine blue $40 \times$ ). 1c: Identification of infiltrated eosinophils in the tumor stroma (arrow) (red congo; $40 \times$ ). 1d: Arrow: FOXP3 ${ }^{+}$cells (counterstaining with Harris hematoxylin; $40 \times$ ). 1e: Arrow: $\mathrm{CD}^{+}{ }^{+}$cells (counterstaining with Harris hematoxylin; $40 \times$ ). $1 \mathrm{f}:$ Arrow: $\mathrm{CD}^{+}$ cells (counterstaining with Harris Hematoxylin; $40 \times$ ). $1 \mathrm{~g}$ : Areas of intratumoral fibrosis (*) (red sirius; $10 \times$ ). $1 \mathrm{~h}$ : area of intratumoral fibrosis after decomposition of the image through ImageJ software. 1i: adjustment of color threshold for fibrosis counting. $1 \mathrm{j}$ : positive control for $\mathrm{CD}^{+}{ }^{+}$staining (dog lymph node, $40 \times$ ). $1 \mathrm{k}$ : positive control for FOXP3 ${ }^{+}($dog lymph node, $40 \times)$.

number of profile cells of other cell types varied according to the histological type.

Comparison between different cell types and the four histological types showed that only plasma cells $(p=.035)$, neutrophils $(p=.0113)$ and macrophages $(p=.0047)$ presented statistically significant differences $(p<.05)$ between two or more histological types (Fig. 1).

Solid carcinomas and carcinomas in mixed tumors presented the highest numbers of plasma cells associated with tumor inflammatory infiltrate (Fig. 1a). Albeit, in the comparison of plasma cells numbers between pairs of groups, a statistical significance was found for $\mathrm{BMT} \times \mathrm{CMT}$ and $\mathrm{BMT} \times \mathrm{SC}$.

A greater number of neutrophils per area unit was found in CMT and TC (Fig. 2b) and statistical significance was shown in the comparison between the pairs of groups TMB $\times$ CTM, CTM $\times$ CS and CS $\times$ TC.

Macrophages were found in less aggressive histologic types, such as BMT and CMT (Fig. 1c). Regarding the relationship between the number of these cells per area unit and pairs of histologic types of tumors, we found a statistical significance in CMT $\times$ SC and CMT $\times$ TC.

In the evaluation of tumor fibrosis percentage for all histologic types, we observed that tubular carcinomas presented the largest areas. When fibrosis was compared between different tumors, significant statistical differences were found between BMT $\times$ CMT and BMT $\times$ TC.

The multivariate statistical analysis involving the same aforementioned parameters showed three correspondences. The first correspondence involved benign mixed tumors, low number of lymphocytes per area unit, low number of plasma cells per area unit and low tumor fibrosis percentage per area unit. The second correspondence involved tubular carcinomas, low number of $\mathrm{CD}^{+}$cells per area unit and high number of neutrophils per area unit. The third one showed a relationship between absence of invasion or micro invasion areas, low number of $\mathrm{CD}^{+}$cells per area unit and moderate number of $\mathrm{CD} 8^{+}$cells per area unit.

\section{Discussion}

Among the inflammatory cells identified in the present study, lymphocytes were the most numerous in all histologic types of canine mammary neoplasms. Although Saeki et al. (2012) and Kim et al. 


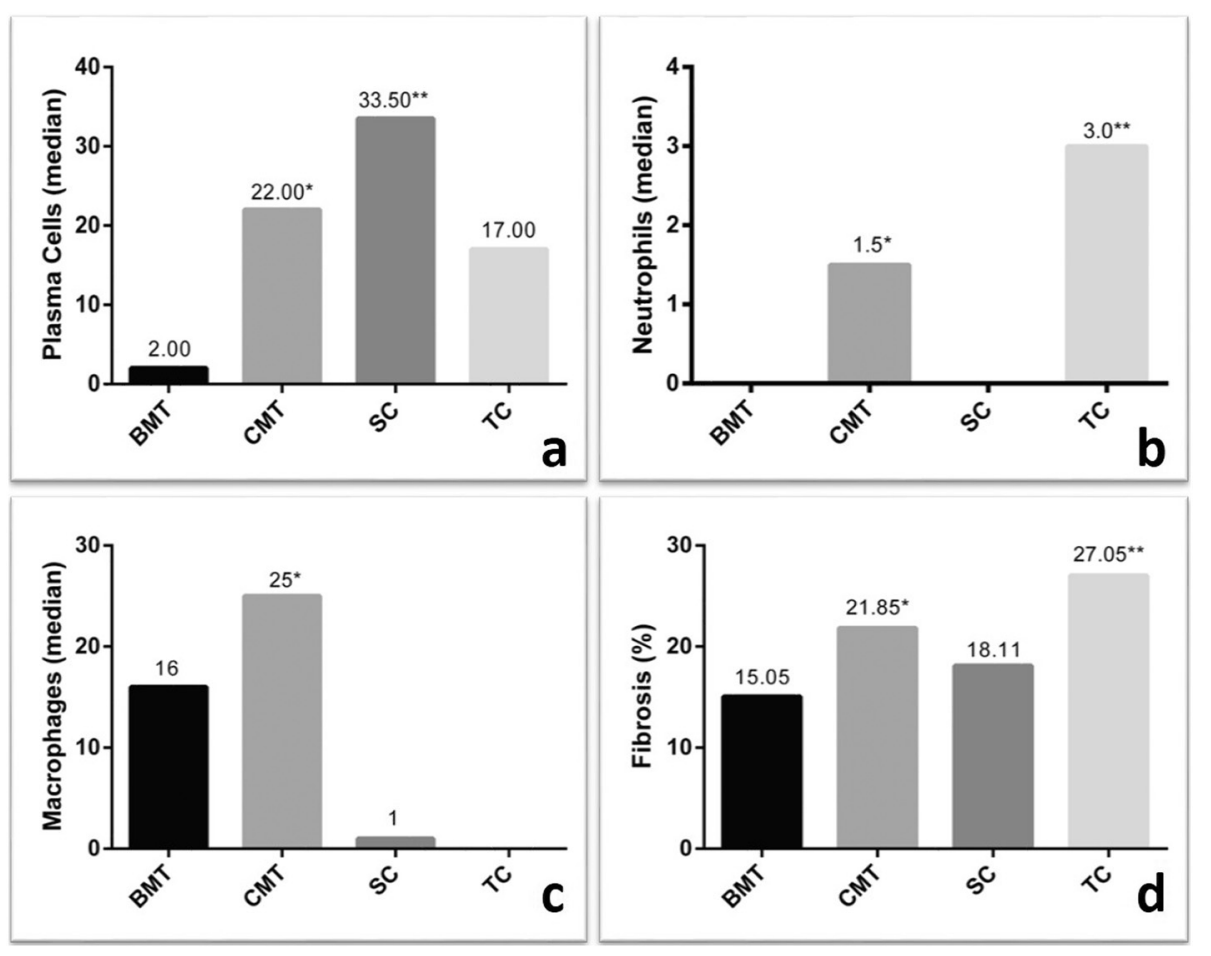

Fig. 2. Graphics showing the medians of plasma cells, neutrophils and macrophages per area unit and percentage of tumor fibrosis area for each histologic type of canine mammary tumor. 2a: Graphic showing median values of plasma cells per histologic type. *Statistical difference when compared with BMT $(p=.03)$. **Statistical difference when compared with BMT ( $p=.01$ ). Fig. 2b: Graphic showing median values of neutrophils per histologic type. *Statistical difference when compared with BMT $(p=.001)$ and SC $(p=.001) .{ }^{* *}$ Statistical difference when compared with TC $(p=.04)$. Fig. $2 c$ : Graphic showing median values of macrophages per histologic type. *Statistical difference when compared with SC $(p=.0004)$ and TC $(p=.007)$. Fig. 2d: Graphic showing median percentage of intratumoral fibrosis per histologic type. *Statistical difference when compared with BMT $(p=.05)$. ${ }^{* * S t a t i s t i c a l}$ difference when compared with BMT $(p=.01)$. BMT: benign mixed tumor. CMT: carcinoma in mixed tumor. SC: solid carcinoma. TC: tubular carcinoma.

(2013) found a relationship between high number of lymphocytes per area unit in the inflammatory infiltrate and aggressiveness in canine mammary tumors, the present study did not verify such relationship, but complemented these data by showing, through multivariate statistical analysis, a relationship between low number of lymphocytes per area unit and less aggressive canine mammary tumor, such as benign mixed tumors. Furthermore, cytotoxic $\mathrm{T}$ and $\mathrm{T}$ helper subtypes were also related to some parameters as discussed below.

According to the studies of Mahmoud et al. (2011), Miyashita et al. (2015) and Preston et al. (2013), the increase in cytotoxic T lymphocytes $\left(\mathrm{CD}^{+}\right)$is associated with better prognosis in human breast cancer, especially in the $\mathrm{CD} 8^{+} / \mathrm{FOXP}^{+}$ratio. In the present study, multivariate statistical analysis showed an important association between tubular carcinomas and low $\mathrm{CD}^{+}$cells. This finding reflects the importance of cytotoxic $\mathrm{T}$ lymphocytes in the fight against tumor cells and reinforces the immunomodulatory action of aggressive tumors, which may be directly responsible for the low number of $\mathrm{CD}^{+}$cells in the inflammatory infiltrate.

However, the high number of profile T helper lymphocytes $\left(\mathrm{CD} 4^{+}\right)$ was associated to both presence of metastases and lower survival rates, especially in the presence of low number of cytotoxic $\mathrm{T}$ lymphocytes $\left(\mathrm{CD}^{+}\right)$, according to Carvalho et al. (2014), Estrela-Lima et al. (2010) and Macchetti et al. (2006). In the present study, no relationship was found between $\mathrm{CD} 4^{+} / \mathrm{CD}^{+}$ratio and the parameters evaluated above. However, it was verified that a low number of $\mathrm{CD}^{+}$cells in canine mammary neoplasms could be related to the absence of invasion or microinvasion areas, leading to the conclusion that $\mathrm{CD}^{+}$cells may play a role, even indirectly, in metastatic mechanisms.

Regarding the macrophages, a higher number of these cells were found in malignant tumors with better prognosis (CMT), but no relationship with survival, invasion and metastasis was observed. These findings contradict what was pointed out by Król et al. (2011, 2014) and Raposo et al. (2014), who verified that an increase of tumor associated macrophages (TAMs) was related to increased invasion and metastasis and decreased survival in patients, which are characteristics of more aggressive neoplasms. However, it is important to point out that, in the present study, immunohistochemistry technique was not used to identify and differentiate subpopulations of M1 or M2 macrophages. The fact that M1 macrophages are related to innate immunity and, therefore, aimed at cytotoxic action, may justify a greater presence of this immunophenotype in carcinomas in mixed tumors, showing a relationship between the high number of macrophages per area unit and less aggressive tumors. An immunohistochemical characterization of macrophages in carcinomas in mixed tumors would be interesting to verify this hypothesis.

Higher numbers of neutrophils appeared mainly in carcinomas in mixed tumors and tubular carcinomas. In multivariate analysis, high number of neutrophil per area unit showed a relationship with tubular carcinomas. This data suggests a relation with more aggressive tumors, as described by Nozawa et al. (2006) and Youn and Gabrilovich (2010). However, solid carcinomas were also expected to exhibit large neutrophil populations, since this was the most aggressive histologic type of this study. Instead, carcinomas in mixed tumors were the neoplasms that showed number of neutrophils per area unit similar to tubular carcinomas. Nevertheless, significant results for lymphocyte/neutrophil and plasma cell/neutrophil ratios in carcinomas in mixed tumors indicate that higher proportions of lymphocytes and plasma cells over neutrophils are related to less aggressive neoplasms, suggesting that these three cell types are closely related in the development and progression of neoplasms.

The values that were found for plasma cells do not agree with the data of Yoon et al. (2011) and Knief et al. (2016) who found an association between the presence of plasma cells and better prognosis in human breast cancer and prolonged survival in human patients with high number of plasma cells and B lymphocytes in esophagogastric transition adenocarcinoma, respectively. In the present study, plasma cells have been shown to be associated with more aggressive neoplasms, as the studies of Fridman et al. (2012), Mohammed et al. (2013) and Lundgren et al. (2016) point out.

As in the studies of De Kruijf et al. (2011) and Gujam et al. (2014), which showed a relationship between larger areas of tumor fibrosis and human patients with worse prognosis, the present study suggests that this relationship may also be true for more aggressive canine mammary tumors, such as tubular carcinomas. In addition, multiple correspondence analysis showed a relationship between low fibrosis percentage and benign mixed tumors, reinforcing the importance of fibrosis in the 


\section{tumor progression.}

Another important observation is that, although solid carcinomas are the most aggressive tumors among the histologic groups, the tumor fibrosis percentage in this group was lower than in tubular carcinomas and even in carcinomas in mixed tumors. This can be explained by the characterization of solid carcinomas, which consists of a proliferation of organized epithelial cells in a solid array with a quantity of stroma varying from little to moderate (Cassali, 2002). Another important factor that concerns the difference observed in carcinomas in mixed tumors is the histological characterization of these neoplasms, which includes the benign proliferation of mesenchymal cells with formation of cartilage or bone, possibly combined with the formation of myxoid fibrous tissue (Misdorp et al., 1999; Cassali et al., 2012), justifying a larger area of tumor fibrosis.

\section{Conclusion}

The results presented in this study suggest that high densities of neutrophils and plasm cells are related to more aggressive mammary neoplasms, while high number of macrophages and $\mathrm{TCD}^{+}$cells and low number of TCD4 ${ }^{+}$lymphocytes are associated with less aggressive neoplasms. The tumor fibrosis percentage has been shown to be a feature that is related to more aggressive mammary tumors, such as tubular carcinomas, which may indicate its use for prognostic purposes also in veterinary medicine.

\section{Acknowledgements}

This study was supported by Coordenação de Aperfeiçoamento de Pessoal de Nível Superior (Capes) and Conselho Nacional de Desenvolvimento Científico e Tecnológico (CNPq).

\section{Appendix A. Supplementary data}

Supplementary data to this article can be found online at https:// doi.org/10.1016/j.rvsc.2018.06.012.

\section{References}

Almatroodi, S.A., McDonald, C.F., Darby, I.A., Pouniotis, D.S., 2016. Characterization of M1/M2 tumour-associated macrophages (TAMs) and Th1/Th2 cytokine profiles in patients with NSCLC. Cancer Microenviron. 9, 1-11. http://dx.doi.org/10.1007/ s12307-015-0174-x.

Amini, R.-M., Aaltonen, K., Nevanlinna, H., Carvalho, R., Salonen, L., Heikkilä, P., Blomqvist, C., 2007. Mast cells and eosinophils in invasive breast carcinoma. BMC Cancer 7, 165. http://dx.doi.org/10.1186/1471-2407-7-165.

Balkwill, F.R., Capasso, M., Hagemann, T., 2012. The tumor microenvironment at a glance. J. Cell Sci. 125, 5591-5596. http://dx.doi.org/10.1242/jcs.116392.

Bingle, L., Brown, N.J., Lewis, C.E., 2002. The role of tumour-associated macrophages in tumour progression: implications for new anticancer therapies. J. Pathol. 196, 254-265. http://dx.doi.org/10.1002/path.1027.

Carretero, R., Sektioglu, I.M., Garbi, N., Salgado, O.C., Beckhove, P., Hämmerling, G.J., 2015. Eosinophils orchestrate cancer rejection by normalizing tumor vessels and enhancing infiltration of CD8(+) T cells. Nat. Immunol. 16, 609-617. http://dx.doi. org/10.1038/ni.3159.

Carvalho, M.I., Pires, I., Prada, J., Queiroga, F.L., 2014. A role for T-lymphocytes in human breast cancer and in canine mammary tumors. Biomed. Res. Int. 2014. http:// dx.doi.org/10.1155/2014/130894.

Cassali, G.D., 2002. Patologias da glândula mamária. In: Nascimento, E.F., Lima, R.S. (Eds.), Patologia da reprodução dos animais domésticos, 3 Ed. vol. 2. Guanabara Koogan, Rio de Janeiro, pp. 131-133.

Cassali, G., Cavalheiro Bertagnolli, A., Ferreira, E., Araújo Damasceno, K., De Oliveira Gamba, C., Bonolo De Campos, C., 2012. Canine mammary mixed tumours: a review. Vet. Med. Int. 2012. http://dx.doi.org/10.1155/2012/274608.

Cassali, G.D., Lavalle, G.E., De Nardi, A.B., Ferreira, E., Bertagnolli, A.C., Estrela-Lima, A., Alessi, A.C., Daleck, C.R., Salgado, B.S., Fernandes, C.G., Sobral, R.A., Amorim, R.L., Gamba, C.O., Damasceno, K.A., Auler, P.A., Magalhães, G.M., Silva, J.O., Raposo, J.B., Ferreira, A.M.R., Oliveira, L.O., Malm, C., Zuccari, D.A.P.C., Tanaka, N.M., Ribeiro, L.R., Campos, L.C., Souza, C.M., et al., 2014. Consensus for the diagnosis, prognosis and treatment of canine mammary tumors - 2013. Brazilian J. Vet. Pathol. 4, 153-180.

Cimpean, A.M., Tamma, R., Ruggieri, S., Nico, B., Toma, A., Ribatti, D., 2017. Mast cells in breast cancer angiogenesis. Crit. Rev. Oncol. Hematol. 115, 23-26. http://dx.doi. org/10.1016/j.critrevonc.2017.04.009.
Dabiri, S., Huntsman, D., Makretsov, N., Cheang, M., Gilks, B., Badjik, C., Gelmon, K., Chia, S., Hayes, M., 2004. The presence of stromal mast cells identifies a subset of invasive breast cancers with a favorable prognosis. Mod. Pathol. 17, 690-695. http:// dx.doi.org/10.1038/modpathol.3800094.

De Kruijf, E.M., Van Nes, J.G.H., Van De Velde, C.J.H., Putter, H., Smit, V.T.H.B.M., Liefers, G.J., Kuppen, P.J.K., Tollenaar, R.A.E.M., Mesker, W.E., 2011. Tumor-stroma ratio in the primary tumor is a prognostic factor in early breast cancer patients, especially in triple-negative carcinoma patients. Breast Cancer Res. Treat. 125, 687-696. http://dx.doi.org/10.1007/s10549-010-0855-6.

De Larco, J.E., Wuertz, B.R.K., Furcht, L.T., 2004. The potential role of neutrophils in promoting the metastatic phenotype of tumors releasing interleukin-8. Clin. Cancer Res. 10, 4895-4900. http://dx.doi.org/10.1158/1078-0432.CCR-03-0760.

De Oliveira, L.O., De Oliveira, R.T., Loretti, A.P., Rodrigues, R., Driemeier, D., 2003 Aspectos epidemiológicos da neoplasia mamária canina. Acta Sci. Vet. 31, 105-110.

Dissemond, J., Weimann, T.K., Schneider, L.A., Schneeberger, A., Scharffetter-Kochanck, K., Goos, M., Wagner, S.N., 2003. Activated neutrophils exert antitumor activity against human melanoma cells: reactive oxygen species-induced mechanisms and their modulation by granulocyte-macrophage-Colony-stimulating factor [2]. J. Invest. Dermatol. 121, 936-938. http://dx.doi.org/10.1046/j.1523-1747.2003. 12475.x.

Estrela-Lima, A., Araújo, M.S.S., Costa-Neto, J.M., Teixeira-Carvalho, A., Barrouin-Melo, S.M., Cardoso, S.V., Martins-Filho, O.A., Serakides, R., Cassali, G.D., 2010. Immunophenotypic features of tumor infiltrating lymphocytes from mammary carcinomas in female dogs associated with prognostic factors and survival rates. BMC Cancer 10, 256. http://dx.doi.org/10.1186/1471-2407-10-256.

Fridlender, Z.G., Sun, J., Kim, S., Kapoor, V., Cheng, G., Worthen, G.S., Albelda, S.M., 2010. Polarization of tumor-associated neutrophil (TAN) phenotype by TGF- $\beta$ : "N1" versus "N2" TAN. Cancer Cell 16, 183-194. http://dx.doi.org/10.1016/j.ccr.2009. 06.017.Polarization.

Fridman, W.H., Pagès, F., Sautès-Fridman, C., Galon, J., 2012. The immune contexture in human tumours: impact on clinical outcome. Nat. Rev. Cancer 12, 298-306. http:// dx.doi.org/10.1038/nrc3245.

Furbert-Harris, P., Parish-Gause, D., Laniyan, I., Hunter, K.A., Okomo-Awich, J., Vaughn, T.R., Forrest, K.C., Howland, C., Abdelnaby, A., Oredipe, O.A., 2003. Inhibition of prostate cancer cell growth by activated eosinophils. Prostate 57, 165-175. http://dx. doi.org/10.1002/pros.10286.

Grivennikov, S.I., Greten, F.R., Karin, M., 2010. Immunity, inflammation, and cancer. Cell 140, 883-899. http://dx.doi.org/10.1016/j.cell.2010.01.025.

Guettinger, Y., Barbin, K., Peipp, M., Bruenke, J., Dechant, M., Horner, H., Thierschmidt, D., Valerius, T., Repp, R., Fey, G.H., Stockmeyer, B., 2010. A recombinant bispecific single-chain fragment variable specific for HLA class II and fc RI (CD89) recruits polymorphonuclear neutrophils for efficient lysis of malignant B lymphoid cells. J. Immunol. 184, 1210-1217. http://dx.doi.org/10.4049/jimmunol.0902033.

Gujam, F.J.A., Edwards, J., Mohammed, Z.M.A., Mcmillan, D.C., 2014. The relationship between the tumour stroma percentage, clinicopathological characteristics and outcome in patients with operable ductal breast cancer. Br. J. Cancer 111, 157-165. http://dx.doi.org/10.1038/bjc.2014.279.

Hasan, J., Byers, R., Jayson, G.C., 2002. Intra-tumoral microvessel density in human solid tumours. Br. J. Cancer 86, 1566-1577.

Hsieh, C.-S., Lee, H.-M., Lio, C.-W.J., 2012. Selection of regulatory T cells in the thymus. Nat. Rev. Immunol. 12, 157-167. http://dx.doi.org/10.1038/nri3155.

Hubert, P., Heitzmann, A., Viel, S., Nicolas, A., Sastre-Garau, X., Oppezzo, P., Pritsch, O., Osinaga, E., Amigorena, S., 2011. Antibody-dependent cell cytotoxicity synapses form in mice during tumor-specific antibody immunotherapy. Cancer Res. 71, 5134-5143. http://dx.doi.org/10.1158/0008-5472.CAN-10-4222.

Kim, M., Grimmig, T., Grimm, M., Lazariotou, M., Meier, E., Rosenwald, A., Tsaur, I., Blaheta, R., Heemann, U., Germer, C.T., Waaga-Gasser, A.M., Gasser, M., 2013. Expression of Foxp3 in colorectal cancer but not in Treg cells correlates with disease progression in patients with colorectal cancer. PLoS One 8, 1-10. http://dx.doi.org/ 10.1371/journal.pone.0053630.

Knief, J., Reddemann, K., Petrova, E., Herhahn, T., Wellner, U., Thorns, C., 2016. High number of profile cells of tumor-infiltrating b-lymphocytes and plasma cells signifies prolonged overall survival in adenocarcinoma of the esophagogastric junction. Anticancer Res. 36, 5339-5345. Doi:http://dx.doi.org/10.21873/anticanres.11107.

Król, M., Pawłowski, K.M., Majchrzak, K., Dolka, I., Abramowicz, A., Szyszko, K., Motyl, T., 2011. Number of profile cells of tumor-associated macrophages (TAMs) and expression of their growth factor receptor MCSF-R and CD14 in canine mammary adenocarcinomas of various grade of malignancy and metastasis. Pol. J. Vet. Sci. 14, 3-10. http://dx.doi.org/10.2478/v10181-011-0001-3.

Król, M., Mucha, J., Majchrzak, K., Homa, A., Bulkowska, M., Majewska, A., Gajewska, M., Pietrzak, M., Perszko, M., Romanowska, K., Pawowski, K., Manuali, E., Hellmen, E., Motyl, T., 2014. Macrophages mediate a switch between canonical and non-canonical wnt pathways in canine mammary tumors. PLoS One 9. http://dx.doi.org/10 1371/journal.pone.0083995.

Lavalle, G., Bertagnolli, A., Tavares, W.L., Ferreira, M.A.N., Cassali, G., 2010. Mast cells and angiogenesis in canine mammary tumor. Arq. Bras. Med. Veterinária e Zootec. 62, 1348-1351. http://dx.doi.org/10.1590/S0102-09352010000600008.

Liu, J., Liu, J., Li, J., Chen, Y., Guan, X., Wu, X., Hao, C., Sun, Y., Wang, Y., Wang, X., 2014. Tumor-stroma ratio is an independent predictor for survival in early cervical carcinoma. Gynecol. Oncol. 8, 11348-11355. http://dx.doi.org/10.1016/j.ygyno. 2013.11.003.

Lundgren, Sebastian, et al., 2016. Prognostic impact of tumour-associated B cells and plasma cells in epithelial ovarian cancer. J. Ovar. Res. 9, 1-9.

Luong, R.H., Baer, K.E., Craft, D.M., Ettinger, S.N., Scase, T.J., Bergman, P.J., 2006. Prognostic significance of intratumoral microvessel density in canine soft-tissue sarcomas. Veterin. pathol. 43, 622-631. 
T.A. de Souza et al.

Research in Veterinary Science 119 (2018) 209-214

Macchetti, A.H., Cosiski, R., Santana, J., De Andrade, M., Ribeiro-Silva, A., Bighetti, S., São, P., Sp, P., 2006. Tumor-infiltrating CD4 + T lymphocytes in early breast cancer reflect lymph node involvement. Clinics 61, 203-208.

Mahmoud, S.M.A., Paish, E.C., Powe, D.G., MacMillan, R.D., Grainge, M.J., Lee, A.H.S., Ellis, I.O., Green, A.R., 2011. Tumor-infiltrating CD8 + lymphocytes predict clinical outcome in breast cancer. J. Clin. Oncol. 29, 1949-1955. http://dx.doi.org/10.1200/ JCO.2010.30.5037.

Mantovani, A., Allavena, P., Sica, A., Balkwill, F., 2008. Cancer-related inflammation. Nature 454, 436-444. http://dx.doi.org/10.1038/nature07205.

Meyerholz, D.K., Griffin, M.A., Castilow, E.M., Varga, S.M., Dkm, P., Smv, M., Roy, J., Carver, L.A., 2010. Comparison of histochemical methods for murine eosinophil detection in a RSV vaccine-enhanced inflammation model. Toxicol. Pathol. 37, 249-255. http://dx.doi.org/10.1177/0192623308329342.Comparison.

Misdorp, W., Else, R.W., Hellmén, E., Lipscomb, E., 1999. Definitions and explanatory notes. In: WHO Histological Classification of Mammary Tumors of the Dog and Cat. Armed Forces Institute of Pathology, Washington, pp. 18-27.

Miyashita, M., Sasano, H., Tamaki, K., Hirakawa, H., Takahashi, Y., Nakagawa, S., Watanabe, G., Tada, H., Suzuki, A., Ohuchi, N., Ishida, T., Dent, R., Hanna, W., Trudeau, M., Rawlinson, E., Sun, P., et al., 2015. Prognostic significance of tumorinfiltrating CD8 + and FOXP3 + lymphocytes in residual tumors and alterations in these parameters after neoadjuvant chemotherapy in triple-negative breast cancer: a retrospective multicenter study. Breast Cancer Res. 17, 124. http://dx.doi.org/10. 1186/s13058-015-0632-x.

Mohammed, Z.M.A., Going, J.J., Edwards, J., Elsberger, B., Mcmillan, D.C., 2013. The relationship between lymphocyte subsets and clinico-pathological determinants of survival in patients with primary operable invasive ductal breast cancer. Br. J. Cancer 109, 1676-1684. http://dx.doi.org/10.1038/bjc.2013.493.

Nozawa, H., Chiu, C., Hanahan, D., 2006. Infiltrating neutrophils mediate the initial angiogenic switch in a mouse model of multistage carcinogenesis. Proc. Natl. Acad. Sci. U. S. A. 2006.

Preston, C.C., Maurer, M.J., Oberg, A.L., Visscher, D.W., Kalli, K.R., Hartmann, L.C.,
Goode, E.L., Knutson, K.L., 2013. The ratios of CD8 + T cells to CD4 + CD25 + FOXP3 + and FOXP3- T cells correlate with poor clinical outcome in human serous ovarian cancer. PLoS One 8, 1-10. http://dx.doi.org/10.1371/journal.pone. 0080063.

Prophet, E.B., Mills, B., Arrington, J.B., Sobin, L.H., 1992. Laboratory Methods in Histotechnology, 1 Ed. American Registry of Pathology, Washington, DC (279 p).

Qian, B.-Z., Pollard, J.W., 2010. Macrophage diversity enhances tumor progression and metastasis. Cell 141, 39-51. http://dx.doi.org/10.1016/j.cell.2010.03.014.

Rajput, A.B., Turbin, D.A., Cheang, M.C., Voduc, D.K., Leung, S., Gelmon, K.A., Gilks, C.B., Huntsman, D.G., 2008. Stromal mast cells in invasive breast cancer are a marker of favourable prognosis: a study of 4,444 cases. Breast Cancer Res. Treat. 107, 249-257. http://dx.doi.org/10.1007/s10549-007-9546-3.

Raposo, T., Gregório, H., Pires, I., Prada, J., Queiroga, F.L., 2014. Prognostic value of tumour-associated macrophages in canine mammary tumours. Vet. Comp. Oncol. 12, 10-19. http://dx.doi.org/10.1111/j.1476-5829.2012.00326.x.

Saeki, K., Endo, Y., Uchida, K., Nishimura, R., Sasaki, N., 2012. Significance of TumorInfiltrating Immune Cells in Spontaneous Canine Mammary Gland Tumor: 140 Cases. pp. 1-4. http://dx.doi.org/10.1292/jvms.11-0118.

Sharma, S., Sharma, M.C., Sarkar, C., 2005. Morphology of angiogenesis in human cancer: a conceptual overview, histoprognostic perspective and significance of neoangiogenesis. Histopathology 46, 481-489.

Yoon, N.K., Maresh, E.L., Shen, D., Elshimali, Y., Apple, S., Mah, V., Bose, S., Chia, D., Chang, H.R., 2011. NIH Public Access. 41. pp. 1794-1801. http://dx.doi.org/10. 1016/j.humpath.2010.06.010.Higher.

Youn, J.-I., Gabrilovich, D.I., 2010. The biology of myeloid-derived suppressor cells: the blessing and the curse of morphological and functional heterogeneity. Eur. J. Immunol. 40, 2969-2975. http://dx.doi.org/10.1002/eji.201040895.The.

Zhang, X., Kelaria, S., Kerstetter, J., Wang, J., 2015. The functional and prognostic implications of regulatory T cells in colorectal carcinoma. J. Gastrointest. Oncol. 10, 307-313. http://dx.doi.org/10.3978/j.issn.2078-6891.2015.017.

214 